\title{
A Null Space Control of Two Wheels Driven Mobile Manipulator Using Passivity Theory
}

\author{
Tsuyoshi Shibata Student Member (Keio University, sbt@sum.sd.keio.ac.jp) \\ Toshiyuki Murakami Member (Keio University, mura@sd.keio.ac.jp)
}

Keywords: motion control, null space, passivity, redundant manipulator, mobile manipulator, work space observer

Recently, robot with redundant degree of freedom motion is utilized in various industrial fields. It is called a redundant manipulator. The control system of redundant manipulator can be divided into work space and null space. This paper focuses on null space motion control. Then, in this research, base of manipulator equips with two wheels driven mobile robot. In addition, it contains passive joint. Fig. 1 shows model of experimental two wheels driven mobile manipulator. Then, control strategy is that stabilizing of the robot system applies to work space observer based position control and null space control while keeping end-effector position. A control design of null space uses passivity based stabilizing. The validity of the proposed approach is verified by simulations and experiments of two wheels driven mobile manipulator.

The dynamics of the robot manipulator

$$
M(\boldsymbol{q}) \ddot{\boldsymbol{q}}+\frac{1}{2} \dot{M}(\boldsymbol{q}) \dot{\boldsymbol{q}}+\mathcal{S}(\boldsymbol{q}, \dot{\boldsymbol{q}}) \dot{\boldsymbol{q}}+\boldsymbol{g}(\boldsymbol{q})=
$$

is given by the Lagrange equation, where $\boldsymbol{q} \in R^{n}$ denotes a joint angle vector.

Using a work space observer, a joint acceleration reference $\ddot{\boldsymbol{q}}^{\text {ref }}$ is written as follows.

$$
\ddot{\boldsymbol{q}}^{r e f}=\ddot{\boldsymbol{q}}_{\text {work }}^{\text {ref }}+\ddot{\boldsymbol{q}}_{\text {null }}^{\text {ref }}
$$

Eq. (2) means that it is possible to design work space controller and null space controller separately.

The work space carries out work space observer based position control. PD controller is shown in

$$
\ddot{\boldsymbol{x}}^{r e f}=K_{P}^{w o r k}\left(\boldsymbol{x}^{c m d}-\boldsymbol{x}\right)+K_{D}^{w o r k}\left(\dot{\boldsymbol{x}}^{c m d}-\dot{\boldsymbol{x}}\right)
$$

where $\boldsymbol{x} \in R^{m}(n>m)$ denotes a position vector, and $K_{P}^{\text {work }}, K_{D}^{\text {work }} \in$ $R^{m \times m}$ are positive definite diagonal matrix.

A design of control uses passivity based stability scheme. That is to say, it denotes construction of feedback control method such that a closed-loop system of robot dynamics becomes passive. Then, Let's consider a Lyapunov function candidate $V(\dot{\boldsymbol{q}}, \boldsymbol{x})$, which is defined by

$$
V(\dot{\boldsymbol{q}}, \boldsymbol{x})=\frac{1}{2} \dot{\boldsymbol{q}}^{T} M(\boldsymbol{q}) \dot{\boldsymbol{q}}+\frac{1}{2}\left(\boldsymbol{x}^{c m d}-\boldsymbol{x}\right)^{T} K_{1}\left(\boldsymbol{x}^{c m d}-\boldsymbol{x}\right) . \cdots
$$

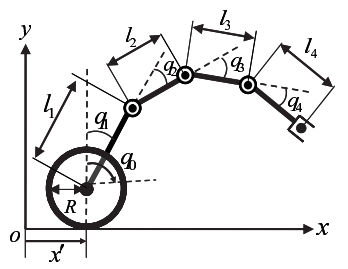

Fig. 1. Model of experimental system
Here, the time differentiation of Eq. (4) along Eq. (1) is calculated as Eq. (5).

$$
\dot{V}(\dot{\boldsymbol{q}}, \boldsymbol{x})=-\dot{\boldsymbol{q}}^{T} K_{2} \dot{\boldsymbol{q}} \leq 0,
$$

where

$$
\boldsymbol{\tau}=J_{a c o}^{T} K_{1}\left(\boldsymbol{x}^{c m d}-\boldsymbol{x}\right)+\boldsymbol{g}(\boldsymbol{q})-K_{2} \dot{\boldsymbol{q}} .
$$

Absolute posture of work space is compensated by work space observer. Null space disturbance is compensated by passivity based controller shown in Eq. (6). In addition, posture of the manipulator is not decided uniquely. Hence, if stability of null space on $\dot{\boldsymbol{q}}$ and $\boldsymbol{x}$ is considered, the manipulator can keep stability of motion. The null space acceleration reference $\ddot{\boldsymbol{q}}_{\text {null }}^{\text {ref }}$ is decided as follows.

$$
\ddot{\boldsymbol{q}}_{\text {null }}^{\text {ref }}=J_{v n}^{-1}\left\{J_{\text {aco }}^{T} K_{1}\left(\boldsymbol{x}^{\text {crmd }}-\boldsymbol{x}\right)+\boldsymbol{g}(\boldsymbol{q})-K_{2} \dot{\boldsymbol{q}}\right\}
$$

Experimental results of each responses are shown in Figs. 2-4. In this paper, a control strategy of null space motion of the two wheels driven mobile manipulator was proposed. The validity of the proposed approach was confirmed by simulation and experimental results.

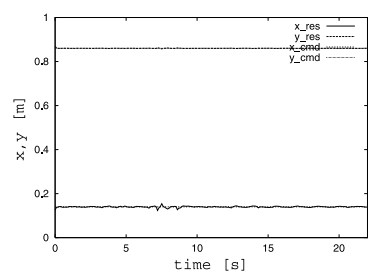

Fig. 2. Position of end-effector

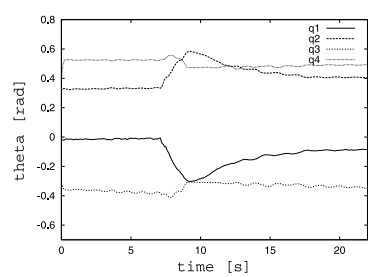

Fig. 3. Theta

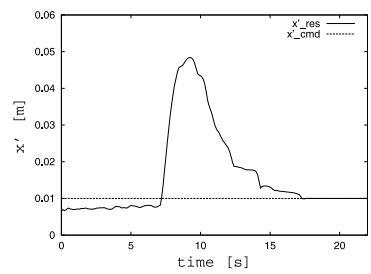

Fig. 4. Position of wheels 


\title{
受動性理論を用いた2 輪駆動型移動マニピュレータにおける 零空間制御
}

\author{
学生員 柴田 剛慶* 正 員 村上 俊之*
}

\author{
A Null Space Control of Two Wheels Driven Mobile Manipulator \\ Using Passivity Theory
}

Tsuyoshi Shibata*, Student Member, Toshiyuki Murakami*, Member

\begin{abstract}
This paper describes a control strategy of null space motion of a two wheels driven mobile manipulator. Recently, robot is utilized in various industrial fields and it is preferable for the robot manipulator to have multiple degrees of freedom motion. Several studies of kinematics for null space motion have been proposed. However stability analysis of null space motion is not enough. Furthermore, these approaches apply to stable systems, but they do not apply unstable systems. Then, in this research, base of manipulator equips with two wheels driven mobile robot. This robot is called two wheels driven mobile manipulator, which becomes unstable system. In the proposed approach, a control design of null space uses passivity based stabilizing. A proposed controller is decided so that closed-loop system of robot dynamics satisfies passivity. This is passivity based control. Then, control strategy is that stabilizing of the robot system applies to work space observer based approach and null space control while keeping end-effector position. The validity of the proposed approach is verified by simulations and experiments of two wheels driven mobile manipulator.
\end{abstract}

キーワード : モーションコントロール, 零空間, 受動性, 圥長マニピュレータ, 移動マニピュレータ, 作業空間オブザーバ

Keywords: motion control, null space, passivity, redundant manipulator, mobile manipulator, work space observer

\section{1. 序 論}

近年，様々な目的で用いられている産業用ロボットには 多様な動き,すなわち, より多自由度性を有するものが要求 されている。このような多自由度性を持つロボットアーム は圥長マニピュレータと呼ばれている。圥長マニピュレー 夕は人間の腕のような動きをすることができる（柔軟性, 融通性）利点があるため, 幅広い応用が期待される。例え ば, 圥長性を用いてアームの先端位置を保ちながらマニピュ レータの姿勢を変えることができる。これらのて長システ ムの特徴を用いた圥長マニピュレータに関する研究は数多 く提案されている(2)(3)(5)(6)。

圥長マニピュレータの制御系は, 作業空間と零空間に分け てそれぞれ設計することができる。作業空間とはマニピュ レータの先端 (手先効果器) 位置の空間を意味し, 零空間と は先端位置に影響を与えない空間を指す。したがって, 零空 間は先端位置の制御に対して非干渉に制御系が設計できる。 本論文ではその零空間における運動制御（零空間制御とよ

\footnotetext{
*慶應義塾大学

干 223-8522 横浜市港北区日吉 3-14-1

Keio University

3-14-1, Hiyoshi, Kouhoku-ku, Yokohama 223-8522
}

ぶ）に焦点を当てる。零空間動作における運動学に関する 研究は数多く提案されている(2)(5)。しかし, 零空間の安定解 析に焦点を当てた研究は十分なされていない。更に, これ らの研究は安定なロボットシステムに用いられており, 不 安定要素を含むシステムに適用されているものもない。そ こで本論文では, 図 1 に示すマニピュレータの土台に 2 輪 駆動の移動ロボットを取り付けた 2 輪駆動型移動冗長マニ ピュレータを用いる。このロボットの特徵は直接制御でき ない受動関節を含んでおり, 倒立振子と等価な不安定なシ ステム (劣駆動システム) となっている。不安定要素を含 みつつも, キャスターを要さない同ロボットは, 電動車椅 子に代表されるキャスター付き 2 輪駆動移動車に比べ, 路 面の変動に対してロバストな走行が期待できる。一般的な 移動マニピュレータの安定化制御についての研究は数多く 報告されているが(9) (12), 先端の位置を保ちながら零空間を 利用してマニピュレータを安定化させる研究はない。本論 文はマニピュレータの先端位置を維持しながら, 作業空間 オブザーバに基づいた制御（位置制御）と零空間制御を用 いて受動関節の動作を安定化させる制御系を構築する。更 に, 車輪運動も零空間として考え, 安定化制御と軌道制御 の融合を図る。提案手法では，作業空間オブザーバにより 手先効果器のロバストな絶対位置制御を実現することがで 


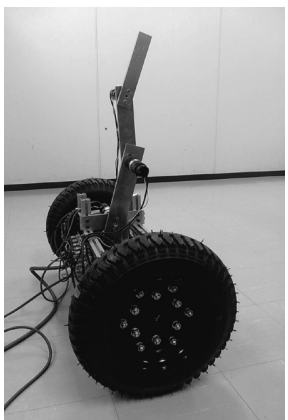

図 12 輪駆動型移動マニピュレータの実験機

Fig. 1. Experimental two wheels driven mobile manipulator.

きる。また，零空間には受動性理論に基づいた安定化コン トローラを設計する。したがって，提案するコントローラ は零空間動作が受動性を満たすように決められている。こ れを受動性に基づく制御という(1)(7)(8)。以下の 2 パターンの シミュレーションと実機による実験を通して提案手法の有 効性を確認する。

(i) 安定化制御 I（零空間動作なし）

(ii) 安定化制御 II（零空間動作あり）

(i) は提案手法の静的安定性を確かめるものであり，(ii) は 車輪の移動に対する 2 輪駆動型移動マニピュレータの安定 性を検証するために行う。つまり，受動関節を含む劣駆動 システムを圥長性を利用した零空間動作により安定化でき ることを示す。

本論文の構成を示す。第 2 章において圥長マニピュレー 夕の動力学と運動学を示す。マニピュレータの動力学は有 本の文献 ${ }^{(1)}$ を参照されたい。同章では, 圥長マニピュレー 夕の制御系において作業空間と零空間の制御系を分ける座 標変換を説明する。第 3 章において作業空間と零空間コン トローラの設計手順を示す。更に，受動性に基づく零空間 コントローラを提案する。第 4, 5 章で提案手法の有効性 を確認するために 2 輪駆動型移動マニピュレータにおいて シミュレーションと実験を行う。最後の第 6 章で結論を述 ベる。

\section{2. 冗長マニピュレータの動力学と運動学}

$\langle 2 \cdot 1\rangle$ 動 力 学 $n$ 個のリンクを持つ多関節ロボット マニピュレータを考える。

手先効果器が自由に動くとき, マニピュレータの運動は 一般化座標 $\boldsymbol{q}=\left(q_{1}, \cdots, q_{n}\right)^{T}$ で記述されるラグランジュ方 程式により支配されている。 $\boldsymbol{q}$ は関節角べクトルである。 このとき, ロボットマニピュレータの動力学方程式はラグ ランジュ方程式により

$$
M(\boldsymbol{q}) \ddot{\boldsymbol{q}}+\frac{1}{2} \dot{M}(\boldsymbol{q}) \dot{\boldsymbol{q}}+\mathcal{S}(\boldsymbol{q}, \dot{\boldsymbol{q}}) \dot{\boldsymbol{q}}+\boldsymbol{g}(\boldsymbol{q})=\boldsymbol{\tau}
$$

と記述することができる。ただしラグランジアンは $L=$ $K-U$ であり, $K(\boldsymbol{q})=\frac{1}{2} \dot{\boldsymbol{q}}^{T} M(\boldsymbol{q}) \dot{\boldsymbol{q}}$ は運動エネルギー, $U(\boldsymbol{q})$ はポテンシャルエネルギーである。 $M(\boldsymbol{q})$ は慣性行列で対
称な正定行列である。更に, $M(\boldsymbol{q})$ のそれぞれの項が定数, もしくは $\boldsymbol{q}$ の構成要素である三角関数なので, 正の定数 $\gamma_{m}$ と $\gamma_{M}$ を用いて

$$
\gamma_{m} I \leq M(\boldsymbol{q}) \leq \gamma_{M} I
$$

と表すことができる。ただし，Iは $n \times n$ の単位行列であ る。 $\tau \in R^{n}$ は関節部のアクチュエータにおいて発生する入 カトルクのベクトルである。 $\mathcal{S}(\boldsymbol{q}, \dot{\boldsymbol{q}})$ は歪対称行列で

$$
\mathcal{S}(\boldsymbol{q}, \dot{\boldsymbol{q}}) \dot{\boldsymbol{q}}=\frac{1}{2}\left[\dot{M}(\boldsymbol{q}) \dot{\boldsymbol{q}}-\left\{\frac{\partial}{\partial \boldsymbol{q}} \dot{\boldsymbol{q}}^{T} M(\boldsymbol{q}) \dot{\boldsymbol{q}}\right\}^{T}\right]
$$

である。また, $\mathcal{S}(\boldsymbol{q}, \dot{\boldsymbol{q}})$ は

$$
\dot{\boldsymbol{q}}^{T} \mathcal{S}(\boldsymbol{q}, \dot{\boldsymbol{q}}) \dot{\boldsymbol{q}}=0
$$

を満足している。 $\boldsymbol{g}(\boldsymbol{q})=\frac{\partial U(\boldsymbol{q})}{\partial \boldsymbol{q}}^{T}$ は重力ベクトルである。

最後に, ロボットマニピュレータは関節のトルク入力 $\tau$ と角速度出力 $\dot{\boldsymbol{q}}$ との間で受動的である。この受動性関係は このシステム理論における力学的エネルギー保存の法則と 入出力関係の操作との橋渡しにおいて重要な役割を果たし ている ${ }^{(1)}$ 。

〈2・2〉 運 動 学 $n$ 個のリンクを持つマニピュレータ において, 作業空間の位置べクトルを $\boldsymbol{x} \in R^{m}(n>m)$ とす ると, キネマティクスは (5)〜 (7) 式のように書ける。

$$
\begin{aligned}
\boldsymbol{x} & =\boldsymbol{f}(\boldsymbol{q}) \ldots \ldots \ldots \\
\dot{\boldsymbol{x}} & =J_{a c o}(\boldsymbol{q}) \dot{\boldsymbol{q}} \cdots \ldots \ldots \\
\ddot{\boldsymbol{x}} & =J_{a c o}(\boldsymbol{q}) \ddot{\boldsymbol{q}}+\dot{J}_{a c o}(\boldsymbol{q}) \dot{\boldsymbol{q}}
\end{aligned}
$$

ここで $J_{a c o} \in R^{m \times n}$ はヤコビ行列であり，(8) 式で表される。

$$
J_{a c o}(\boldsymbol{q})=\frac{\partial \boldsymbol{f}(\boldsymbol{q})}{\partial \boldsymbol{q}} .
$$

(7) 式の逆運動学は

$$
\ddot{\boldsymbol{q}}=J_{a c o}^{+}\left(\ddot{\boldsymbol{x}}-\dot{J}_{a c o} \dot{\boldsymbol{q}}\right)+\left(I-J_{a c o}^{+} J_{a c o}\right) \ddot{\boldsymbol{\phi}}
$$

となる。 $J_{a c o}^{+}$はヤコビ行列の擬似逆行列であり, 以下のよ うに定義されている。

$$
J_{\text {aco }}^{+}=J_{\text {aco }}^{T}\left(J_{a c o} J_{\text {aco }}^{T}\right)^{-1}
$$

(9) 式の右辺において, $\ddot{\boldsymbol{\phi}}$ は零空間の入力ベクトルである。 (9) 式を用いることで, 関節空間と作業空間の加速度参照值 は圥長マニピュレータの関節空間に分解される。

$\langle\mathbf{2} \cdot \mathbf{3}\rangle$ 零空間における関節空間の加速度参照值 静 力学と運動学で関節空間におけるマニピュレータの動力学 を考えると, 等価な運動方程式を作業空間において導き出 すことができる。

提案手法において, 関節の加速度参照値は

$$
\ddot{\boldsymbol{q}}^{r e f}=J_{a c o}^{+} \ddot{\boldsymbol{x}}^{r e f} \text {. }
$$

で与える。ここで, 上付文字 $r e f$ は運動指令值を意味する。 関節の加速度参照值に基づいた零空間指令を考えるため 


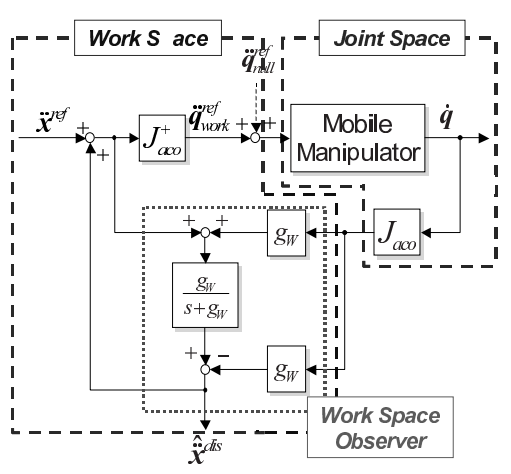

図 2 作業空間オブザーバ

Fig. 2. Work space observer.

に, 任意の関節加速度 $\ddot{\boldsymbol{q}}_{\text {null }}^{\text {ref }}$ を (11) 式に加える。そのとき, 関節加速度参照值 $\ddot{\boldsymbol{q}}^{r e f}$ は以下のように再定義される。

$$
\ddot{\boldsymbol{q}}^{r e f}=J_{\text {aco }}^{+} \ddot{\boldsymbol{x}}^{\text {ref }}+\ddot{\boldsymbol{q}}_{\text {null }}^{r e f}
$$

(7) 式において $\ddot{\boldsymbol{q}}=\ddot{\boldsymbol{q}}^{\text {ref }}$ とし，(7) 式と (12) 式を用いると, 作業空間における加速度偏差 $\ddot{\boldsymbol{e}}_{\text {work }}$ は以下のように与えら れる。

$$
\begin{aligned}
\ddot{\boldsymbol{e}}_{w o r k} & =\ddot{\boldsymbol{x}}^{r e f}-\ddot{\boldsymbol{x}} \\
& =-J_{a c o} \ddot{\boldsymbol{q}}_{\text {null }}^{r e f}-\dot{J}_{a c o} \dot{\boldsymbol{q}}
\end{aligned}
$$

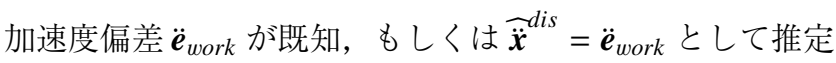
される場合, 加速度偏差を作業空間において補償するため, 推定加速度偏差をフィードバックする。そのとき, (12) 式 は以下のように書き換えられる。実際, $\ddot{\boldsymbol{e}}_{\text {work }}$ は図 2 に示さ れる作業空間オブザーバによって推定される。

$$
\ddot{\boldsymbol{q}}^{r e f}=J_{a c o}^{+}\left(\ddot{\boldsymbol{x}}^{r e f}+\widehat{\ddot{x}}^{d i s}\right)+\ddot{\boldsymbol{q}}_{\text {null }}^{r e f} .
$$

$\widehat{\ddot{x}}^{d i s}=\ddot{\boldsymbol{e}}_{\text {work }}$ とし, (13) 式を (14) 式に代入すると,

$$
\ddot{\boldsymbol{q}}^{r e f}=J_{a c o}^{+}\left(\ddot{\boldsymbol{x}}^{r e f}-\dot{J}_{a c o} \dot{\boldsymbol{q}}\right)+\left(I-J_{a c o}^{+} J_{a c o}\right) \ddot{\boldsymbol{q}}_{\text {null }}^{r e f}
$$

を得ることができる。(15) 式は作業空間で推定された加速 度偏差のフィードバックにより行列 $\left(I-J_{a c o}^{+} J_{a c o}\right)$ を計算 することなく零空間動作を実現できることを示している。 $J_{\text {aco }}^{+}\left(\ddot{\boldsymbol{x}}^{r e f}+\widehat{\ddot{\boldsymbol{x}}}^{d i s}\right)$ を $\ddot{\boldsymbol{q}}_{\text {work }}^{\text {ref }}$ とすると, (14) 式は

$$
\ddot{\boldsymbol{q}}^{r e f}=\ddot{\boldsymbol{q}}_{\text {work }}^{r e f}+\ddot{\boldsymbol{q}}_{\text {null }}^{r e f} .
$$

と書ける。(16) 式は作業空間コントローラと零空間コント ローラを分けて設計することができることを意味している。 したがって，作業空間オブザーバは作業空間における加速 度偏差を補償し，零空間動作を理想的に実現するために用 いられる。加速度偏差 $\widehat{\ddot{x}}^{d i s}$ が作業空間オブザーバによって 推定されることは既に確かめられている( ${ }^{(3)}$ 。

\section{3. 作業空間と零空間のコントローラ設計}

本章では，作業空間コントローラと零空間コントローラ
の設計手順を説明する。作業空間では, 作業空間オブザーバ に基づいた PD コントローラを用いる。作業空間オブザー バは作業空間における外乱 $\widehat{\ddot{x}}^{d i s}$ を抑制できる。したがって, 作業空間と零空間は (16) 式で示される関節空間でそれぞれ 分離されたコントローラ設計が可能となる。

〈3・1〉 作業空間コントローラ 作業空間は加速度制 御系に基ついた位置制御を行う。その際, 加速度指令值は

$$
\ddot{\boldsymbol{x}}^{r e f}=K_{P}^{\text {work }}\left(\boldsymbol{x}^{c m d}-\boldsymbol{x}\right)+K_{D}^{w o r k}\left(\dot{\boldsymbol{x}}^{\text {cmd }}-\dot{\boldsymbol{x}}\right)
$$

で示される。ただし $\boldsymbol{x}^{c m d} \in R^{m}$ は位置指令值のべクトルで あり， $K_{P}^{\text {work }}, K_{D}^{\text {work }} \in R^{m \times m}$ は正定対角行列である。さらに 作業空間オブザーバを用い, 推定された外乱加速度 $\widehat{\ddot{x}}^{d i s}$ は 図 2 に示すようにフィードバックされる。図 2 は作業空間 オブザーバのブロック線図である(3)(4)。

$\langle\mathbf{3} \cdot 2\rangle$ 零空間動作の安定解析本節では, 零空間コ ントローラ設計のための安定解析について述べる。作業空 間における外乱は作業空間オブザーバによって補償でき安 定性の向上が行えるが，零空間制御に対する外乱について は補償されているとは限らない。ここで, (1)式のダイナミ クスを零空間における外乱と仮定し, 受動性に基ついた安 定化手法を用いてコントローラの設計を行う。つまり，ロ ボットのダイナミクス (1) 式を含めた閉ループ構造が受動 性を満たすようなフィードバックコントローラを構築し, 零空間の加速度参照值 $\ddot{\boldsymbol{q}}_{\text {null }}^{\text {ref }}$ として適用する。受動性を満た したコントローラは外乱抑制特性をもつので(7)(8), 零空間に おける外乱を補償することができる。ここで, 以下に示す 蓄積関数 $V(\dot{\boldsymbol{q}}, \boldsymbol{x})$ を考える。

$$
\begin{aligned}
V(\dot{\boldsymbol{q}}, \boldsymbol{x})= & \frac{1}{2} \dot{\boldsymbol{q}}^{T} M(\boldsymbol{q}) \dot{\boldsymbol{q}} \\
& +\frac{1}{2}\left(\boldsymbol{x}^{c m d}-\boldsymbol{x}\right)^{T} K_{1}\left(\boldsymbol{x}^{c m d}-\boldsymbol{x}\right) .
\end{aligned}
$$

ただし $K_{1} \in R^{m \times m}$ は正定行列もしくは準正定行列で，任意 に決めることができる。したがって，(18)式は $\dot{\boldsymbol{q}}$ と $\boldsymbol{x}$ に関 して正定もしくは準正定な関数となる。ここで, (1) 式と (6) 式に沿った (18) 式の時間微分は (19) 式のように計算さ れる。

$$
\begin{aligned}
& \dot{V}(\dot{\boldsymbol{q}}, \boldsymbol{x})=\dot{\boldsymbol{q}}^{T}\left\{\boldsymbol{\tau}-J_{a c o}^{T} K_{1}\left(\boldsymbol{x}^{c m d}-\boldsymbol{x}\right)-\boldsymbol{g}(\boldsymbol{q})\right\} \cdots \cdots \\
& \text { そこで, } \boldsymbol{\tau} \text { を } \\
& \boldsymbol{\tau}=J_{a c o}^{T} K_{1}\left(\boldsymbol{x}^{c m d}-\boldsymbol{x}\right)+\boldsymbol{g}(\boldsymbol{q})+\boldsymbol{v} \cdots \cdots \cdots \cdots \cdots
\end{aligned}
$$

と置き換えると，(19) 式は

$$
\dot{V}(\dot{\boldsymbol{q}}, \boldsymbol{x})=\dot{\boldsymbol{q}}^{T} \boldsymbol{v}
$$

となる。ここで，この $v \in R^{n}$ は受動性を証明するための新 しい入力ベクトルを意味する。したがって, 出力を $\dot{\boldsymbol{q}}$, 入 力を $\boldsymbol{v}$ とする，(20) 式より(1) 式は受動的であることが わかる。ここで更に, vを 


$$
\boldsymbol{v}=-K_{2} \dot{\boldsymbol{q}}
$$

と置くと，(21) 式は以下のように書き換えられる。

$$
\dot{V}(\dot{\boldsymbol{q}}, \boldsymbol{x})=-\dot{\boldsymbol{q}}^{T} K_{2} \dot{\boldsymbol{q}} \leq 0
$$

ただし $K_{2} \in R^{n \times n}$ は正定対角行列であり，任意に決めること ができる。したがって, システムの平衡点 $(\dot{\boldsymbol{q}}, \boldsymbol{x})=\left(\boldsymbol{0}, \boldsymbol{x}^{\mathrm{cmd}}\right)$ は入力

$$
\boldsymbol{\tau}=J_{a c o}^{T} K_{1}\left(\boldsymbol{x}^{c m d}-\boldsymbol{x}\right)+\boldsymbol{g}(\boldsymbol{q})-K_{2} \dot{\boldsymbol{q}}
$$

によって安定になることがわかる。しかし, 蓄積関数 (18) は $\dot{\boldsymbol{q}}$ と $\boldsymbol{q}$ もしくは $\boldsymbol{q}$ と $\boldsymbol{x}$ については正定もしくは準正定で はない。 $\boldsymbol{x}$ と $\boldsymbol{q}$ の次元が等しいときの漸近安定性について は証明されているが(1)，マニピュレータは圥長性を持って いるため姿勢は一意に決めることができない。したがって， $\boldsymbol{q}$ について正定もしくは準正定とすることが難しい。この とき, 加速度制御系が構成されているため, 通常 (24) 式の 右辺第 3 項の零空間ダンピングにより姿勢を安定化させる ことができるが，受動関節を含んでいる劣駆動システムの ため, 単純な零空間ダンピングのみでは作業空間をも安定 化することができない。しかし，(24) 式の右辺第 1 項用い ることにより，受動関節に起因する作業空間と零空間への 影響を零空間で制御することができる。よって，零空間に おける $\dot{\boldsymbol{q}}$ と $\boldsymbol{x}$ についての安定性さえ考慮されていれば，マ ニピュレータは安定性を保つことができると考えられる。 このことは, 蓄積関数 (18) が準正定行列でも十分であるこ とを示している。

$\langle\mathbf{3} \cdot \mathbf{3}\rangle$ 零空間コントローラ $\langle 3 \cdot 2\rangle$ 節より零空間にお ける加速度参照值, つまり零空間コントローラ $\ddot{\boldsymbol{q}}_{\text {null }}^{\text {ref }}$ は以下 の (25) 式と決める。

$$
\ddot{\boldsymbol{q}}_{\text {null }}^{r e f}=J_{\text {vn }}^{-1}\left\{J_{\text {aco }}^{T} K_{1}\left(\boldsymbol{x}^{c m d}-\boldsymbol{x}\right)+\boldsymbol{g}(\boldsymbol{q})-K_{2} \dot{\boldsymbol{q}}\right\} \cdots
$$

ただし， $J_{v n}=I \in R^{n \times n}$ は仮想慣性行列である。(25) 式は 作業空間における位置指令と零空間における安定性を考慮 している。図 3 に提案手法全体のブロック線図を示す。

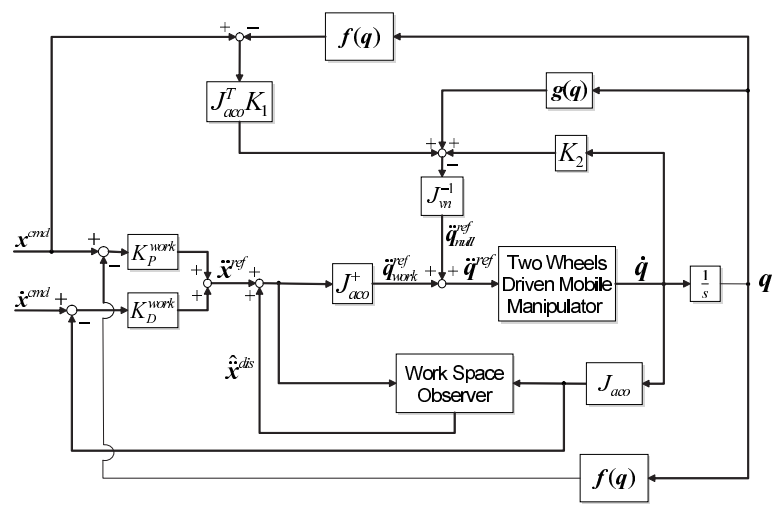

困 3 提案手法の全体のブロック線図

Fig. 3. Whole block diagram of proposed method.

\section{4. シミュレーション}

〈4・1〉 シミュレーション設定 本章では, 提案する手 法を確認するためにシミュレーションを行う。図 4 に 2 輪 駆動型移動マニピュレータの実機のモデルを, 表 1 に物理 パラメータを示す。この物理パラメータは実機に則したも のとなっている。車輪の回転角 $q_{0}$ を含んだ関節角べクトル を $\boldsymbol{q}=\left(q_{0}, q_{1}, q_{2}, q_{3}, q_{4}\right)^{T}$ と定義する。また $\boldsymbol{x}=\left(x, y, x^{\prime}\right)^{T}$ は位置べクトルで， $x^{\prime}$ は車輪の移動距離を意味している。 つまり，車輪の移動を零空間動作に含めて考える。ここで $q_{1}$ (リンク 1) は受動関節であり, $R$ は車輪の半径である。 図 4 に示す 2 輪駆動型移動マニピュレータのダイナミクス については，ラグランジュ方程式を用いることにより，容 易に計算することができる。

以下に示す 2 つの゚ターンのシミュレーションを行う。

(i) 安定化制御 I (零空間動作なし)

(ii) 安定化制御 II（零空間動作あり）

最初に特異姿勢を回避するため角度制御を行い, 先端位 置の位置制御により初期姿勢に移行する。その結果, マニ ピュレータの先端と移動ロボットの初期位置は以下のよう になる。

$$
\boldsymbol{x}(0)=\left[\begin{array}{lll}
0.14 & 0.86 & G_{x}
\end{array}\right]^{T}
$$

$G_{x}$ はマニピュレータの重心位置の $x$ 座標であり, 以下のよ うに計算される。

表 1 移動マニピュレー夕に関するパラメータ

Table 1. Parameters of mobile manipulator.

\begin{tabular}{|c|c|c|c|}
\hline & length [m] & & mass [kg] \\
\hline$R$ & 0.20 & $m_{0}$ & 8.4 \\
\hline$l_{1}$ & 0.11 & $m_{1}$ & 12.7 \\
\hline$l_{2}$ & 0.20 & $m_{2}$ & 1.02 \\
\hline$l_{3}$ & 0.20 & $m_{3}$ & 0.72 \\
\hline$l_{4}$ & 0.18 & $m_{4}$ & 0.22 \\
\hline
\end{tabular}

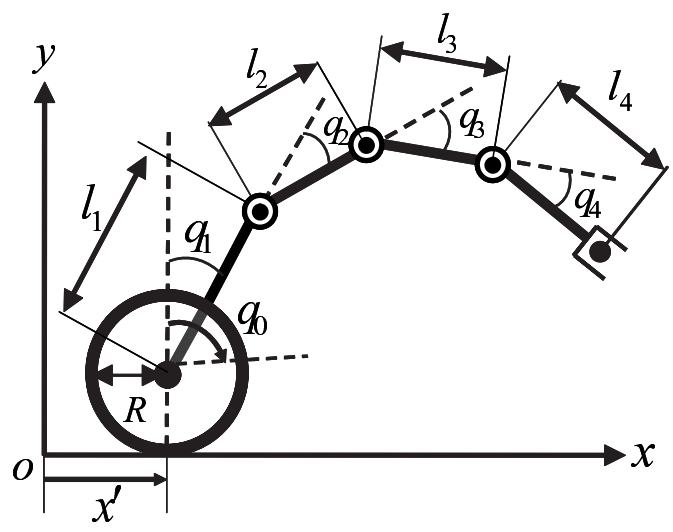

図 42 輪駆動型移動マニピュレータのモデル

Fig. 4. Model of two wheels driven mobile manipulator. 


$$
\begin{aligned}
& G_{x}=\frac{a_{1}+a_{2}+a_{3}+a_{4}}{m_{1}+m_{2}+m_{3}+m_{4}} \ldots \ldots \ldots \ldots . \\
& a_{1}=m_{1} l_{1} \sin q_{1}, a_{2}=m_{2} l_{2} \sin \left(q_{1}+q_{2}\right), \\
& a_{3}=m_{3} l_{3} \sin \left(q_{1}+q_{2}+q_{3}\right), \\
& a_{4}=m_{4} l_{4} \sin \left(q_{1}+q_{2}+q_{3}+q_{4}\right)
\end{aligned}
$$

このとき提案手法を投入するまで, 作業空間オブザーバ, 零 空間の速度フィードバックと移動ロボットの重心位置への 移動によりマニピュレータの初期姿勢を安定化する。時間 ごとのシミュレーション手順は以下の通りである。

• $0 \sim 1.0 \mathrm{~s}$ : 特異姿勢を回避するための角度制御

・ $1.0 \sim 5.0 \mathrm{~s}$ : 移動ロボットと手先位置の位置制御（初期 姿勢 $x(0))$

- $5.0 \mathrm{~s} \sim$ : 提案手法

ただし，シミュレーションにおいて，受動関節と車輪間の 粘性摩擦は考えていない。

〈4·2〉 シミュレーション 1 : 安定化制御 I シミュ レーション 1 は提案手法の静的安定性を確認するために行 う。先端位置と移動ロボットの位置指令は

$$
\begin{aligned}
\boldsymbol{x}^{c m d} & =\left[\begin{array}{lll}
0.14 & 0.86 & G_{x}
\end{array}\right]^{T}, \\
\dot{\boldsymbol{x}}^{\text {cmd }} & =\left[\begin{array}{lll}
0.0 & 0.0 & 0.0
\end{array}\right]^{T}
\end{aligned}
$$

である。作業空間コントローラはPD コントローラ (17) を 用いる。 $K_{P}^{\text {work }}$ と $K_{D}^{\text {work }}$ は以下ように決める。

$$
K_{P}^{\text {work }}=\operatorname{diag}(900,900,0), \quad K_{D}^{\text {work }}=\operatorname{diag}(60,60,0)
$$

作業空間オブザーバゲイン $g_{W}$ は $50 \mathrm{rad} / \mathrm{s}$ とする。上記の $\mathrm{PD}$ コントローラゲインは車輪への入力が受動性に基づく 零空間コントローラのみであることを意味している。零空 間コントローラ (25) 式において，受動関節であるリンク 1 は制御することができないのでゲイン行列 $K_{1}$ と $K_{2}$ は

$$
K_{1}=\left[\begin{array}{lll}
1 & 1 & 1 \\
1 & 1 & 1 \\
1 & 1 & 1
\end{array}\right], \quad K_{2}=\operatorname{diag}(60,0,60,60,60)
$$

とする。図 5 と図 6 にそれぞれ先端位置と角度の応答を 示す。

〈4·3〉 シミュレーション 2 : 安定化制御 II シミュ レーション 2 は車輪の移動に対する移動マニピュレー夕の 安定性を確認するために行う。先端位置と移動ロボットの 位置指令は

$$
\begin{aligned}
\boldsymbol{x}^{c m d} & =\left[\begin{array}{lll}
0.14 & 0.86 & x^{\prime c m d}
\end{array}\right]^{T}, \\
\dot{x}^{c m d} & =\left[\begin{array}{lll}
0.0 & 0.0 & 0.0
\end{array}\right]^{T}
\end{aligned}
$$

である。このとき，移動ロボットの移動距離指令 $x^{\prime c m d}$ を $0.050 \mathrm{~m}$ としてシミュレーションを行う。作業空間コント ローラは PD コントローラ (17) を用いる。 $K_{P}^{\text {work }}$ と $K_{D}^{\text {work }}$ は以下ように決める。

$$
K_{P}^{\text {work }}=\operatorname{diag}(900,900,200), \quad K_{D}^{\text {work }}=\operatorname{diag}(60,60,60)
$$

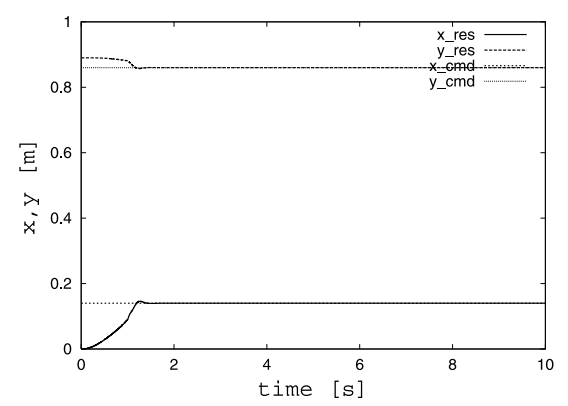

困 5 位置応答

Fig. 5. Position responses.

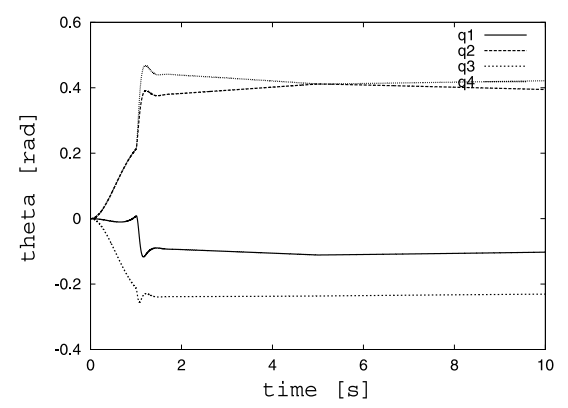

図 6 角度応答

Fig. 6. Theta responses.

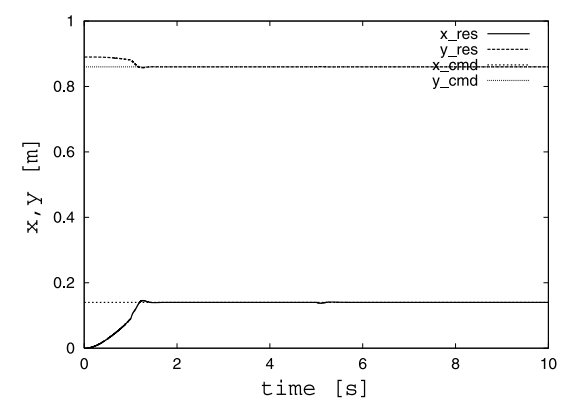

図 7 先端の位置応答

Fig. 7. Position responses of end-effector.

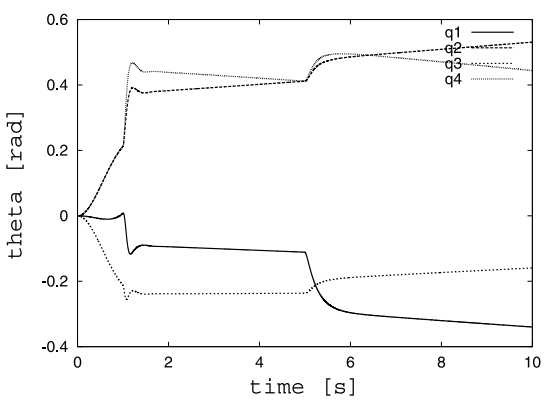

図 8 角度応答

Fig. 8. Theta response.

作業空間オブザーバゲイン $g_{W}$ は $50 \mathrm{rad} / \mathrm{s}$ とする。零空間 コントローラ (25)において, 受動関節であるリンク 1 は制 御することができないのでゲイン行列 $K_{1}$ と $K_{2}$ は 


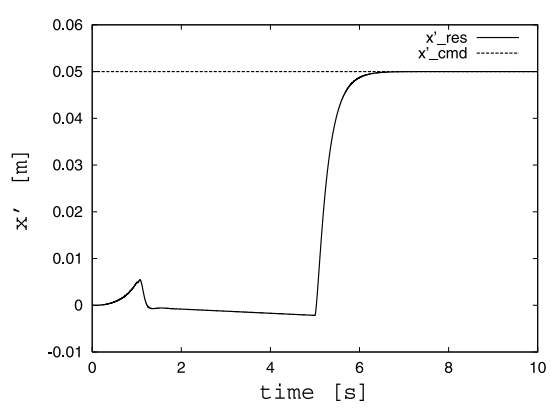

図 9 車輪の位置応答

Fig. 9. Position response of wheels.

$$
K_{1}=\left[\begin{array}{lll}
1 & 1 & 1 \\
1 & 1 & 1 \\
1 & 1 & 1
\end{array}\right], \quad K_{2}=\operatorname{diag}(60,0,60,60,60)
$$

とする。図 7 と図 8 はそれぞれ先端位置と角度の応答を示 している。また，車輪の位置応答を図 9 に示す。

$\langle\mathbf{4} \cdot \mathbf{4}\rangle \quad$ シミュレーション結果と考察すべてのシミュ レーション結果から，受動関節を含んだ移動マニピュレー 夕は倒れることなく安定化することができ，先端位置はそ れぞれの指令值に収束した。また，シミュレーション 2 に おいても車輪の移動に対する安定性を示すことができた。 これらの結果から，提案手法の有効性が確認された。

\section{5. 実験}

〈5・1〉実験内容本章では，シミュレーションと同 様の条件で実機による実験を行う。制御することのできな い受動関節 $q_{1}$ の角度は傾斜センサによって測定する。

最初に特異姿勢を回避するため角度制御を行い，先端位 置の位置制御により初期姿勢に移行する。その結果，マニ ピュレータの先端と移動ロボットの初期位置は以下のよう になる。

$$
\boldsymbol{x}(0)=\left[\begin{array}{lll}
0.14 & 0.86 & G_{x}
\end{array}\right]^{T}
$$

重心の $x$ 座標 $G_{x}$ は (26) 式により計算される。このとき提 案手法を投入するまで，作業空間オブザーバ，零空間の速 度フィードバックと移動ロボットの重心位置への移動によ りマニピュレータの初期姿勢を安定化する。また，実験結 果のグラフの横軸は初期姿勢に移行してからの時間経過を 表示している。

〈5・2〉実験 1 : 安定化制御I 実験 1 はシミュレーショ ン 1 と同様に提案手法の静的安定性を確認するために行う。 先端位置と移動ロボットの位置指令は

$$
\begin{aligned}
\boldsymbol{x}^{c m d} & =\left[\begin{array}{lll}
0.14 & 0.86 & G_{x}
\end{array}\right]^{T}, \\
\dot{x}^{c m d} & =\left[\begin{array}{lll}
0.0 & 0.0 & 0.0
\end{array}\right]^{T}
\end{aligned}
$$

である。作業空間コントローラ (17) の PD ゲイン，作業空 間オブザーバゲイン $g_{W}$, 零空間コントローラ $(25)$ のゲイ ン $K_{1}, K_{2}$ はシミュレーション 1 と同じ值を用いた。

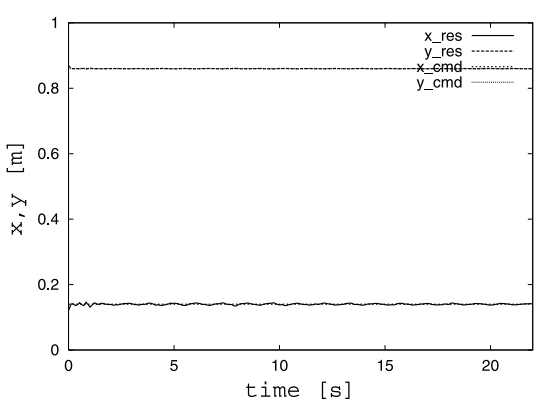

図 10 位置応答

Fig. 10. Position responses.

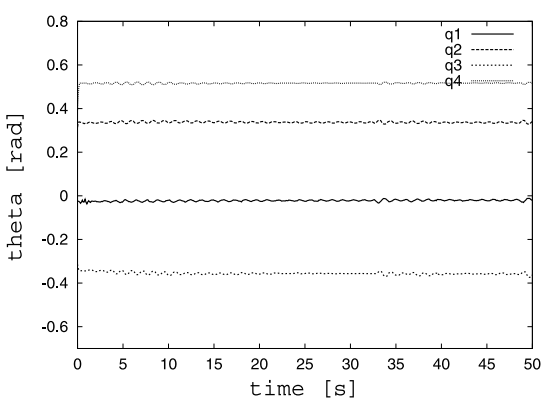

図 11 角度応答

Fig. 11. Theta responses.

ここで，人間による外乱入力を与えたときの実験結果を 示す。外乱入力はリンク 1 (受動関節) を押すことにより 加えた。このとき, $10.4 \mathrm{~s}$ のときに提案手法を適用し，人 の入力による外乱を $33.0 \mathrm{~s}$ のときに加えた。図 10 と図 11 にそれぞれの先端位置と角度の応答を示す。

$\langle\mathbf{5} \cdot 3\rangle$ 実験 2 : 安定化制御 II 実験 2 はシミュレー ション 2 と同様に車輪の移動に対する移動マニピュレー夕 の安定性を確認するために行う。先端位置と移動ロボット の位置指令は

$$
\begin{aligned}
\boldsymbol{x}^{\text {cmd }} & =\left[\begin{array}{lll}
0.14 & 0.86 & x^{\text {cmd }}
\end{array}\right]^{T}, \\
\dot{\boldsymbol{x}}^{\text {cmd }} & =\left[\begin{array}{lll}
0.0 & 0.0 & 0.0
\end{array}\right]^{T}
\end{aligned}
$$

である。このとき，3 パターンの移動ロボットの移動距離 指令 $x^{\prime c m d}$ に対して実験を行う。

(Case 2-1) $\quad x^{\prime c m d}=0.010[\mathrm{~m}]$

(Case 2-2) $\quad x^{\prime c m d}=0.015[\mathrm{~m}]$

(Case 2-3) $\quad x^{\text {ctmd }}=0.020[\mathrm{~m}]$ $x^{\prime c m d}$ は先端位置を維持したまま零空間動作として可能な 範囲で決定している。作業空間コントローラは PD コント ローラ (17) を用いる。 $K_{P}^{\text {work }}$ と $K_{D}^{\text {work }}$ は以下ように与える。

$$
\begin{aligned}
& K_{P}^{\text {work }}=\operatorname{diag}\left(900,900, k_{P}^{\text {mobile }}\right), \\
& K_{D}^{\text {work }}=\operatorname{diag}(60,60,60)
\end{aligned}
$$

ここで Case 2-1 のときは $k_{P}^{\text {mobile }}=200$, Case 2-2 のときは $k_{P}^{\text {mobile }}=100$, Case 2-3 のときは $k_{P}^{\text {mobile }}=20$ とした。作業 空間オブザーバゲイン $g_{W}$, 零空間コントローラ $(25)$ のゲ イン $K_{1}, K_{2}$ はシミュレーション 2 と同じ值を用いた。 


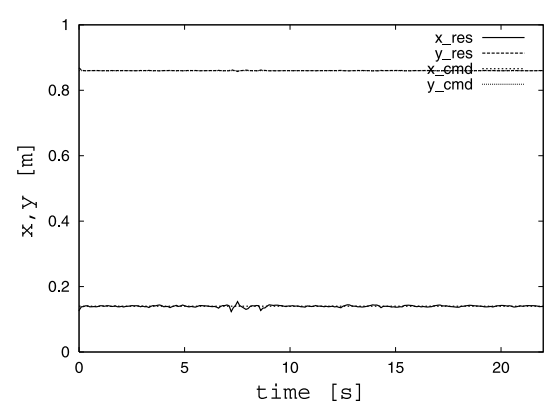

困 12 先端の位置応答 (Case 2-1)

Fig. 12. Position responses of end-effector (Case 2-1).

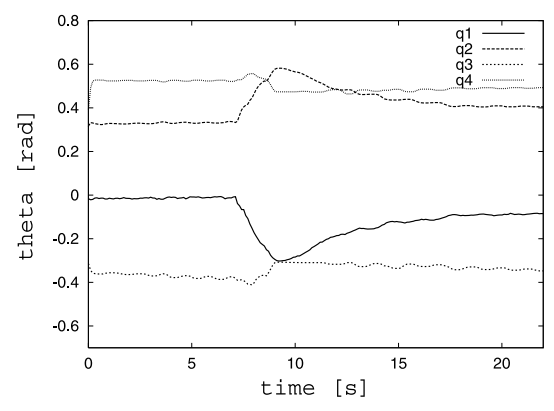

図 13 角度応答 (Case 2-1)

Fig. 13. Theta responses (Case 2-1).

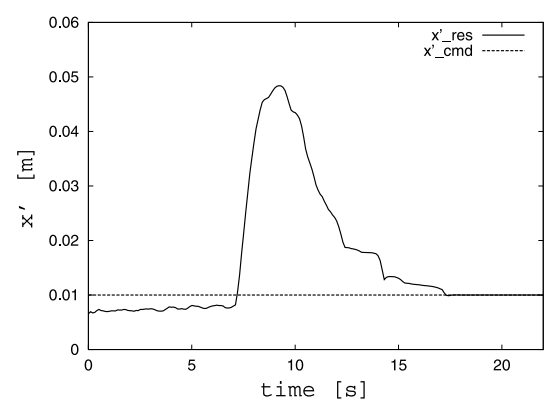

図 14 車輪の位置応答 (Case 2-1)

Fig. 14. Position response of wheels (Case 2-1).

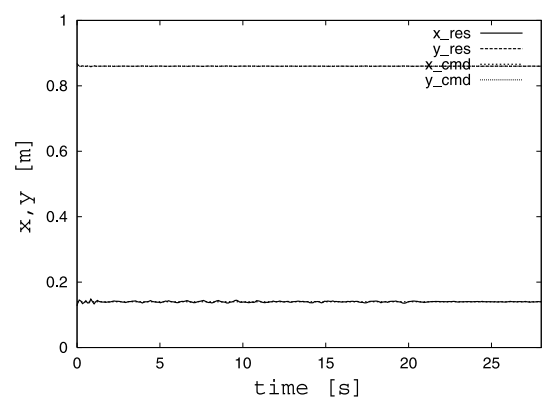

図 15 先端の位置応答 (Case 2-2)

Fig. 15. Position responses of end-effector (Case 2-2).

Case 2-1 は, 7.1 s のときに提案手法を適用した。図 12〜 図 14 にCase 2-1 のときのそれぞれの先端位置, 角度, 車 輪の応答を示す。Case 2-2 は，9.9s のときに提案手法を適 用した。図 15～図 17 にCase 2-2 のときのそれぞれの先端 位置, 角度, 車輪の応答を示す。Case 2-3 は, $18.4 \mathrm{~s}$ のと

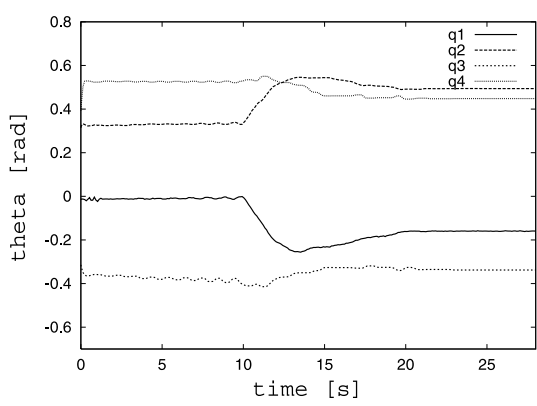

図 16 角度応答 (Case 2-2)

Fig. 16. Theta responses (Case 2-2).

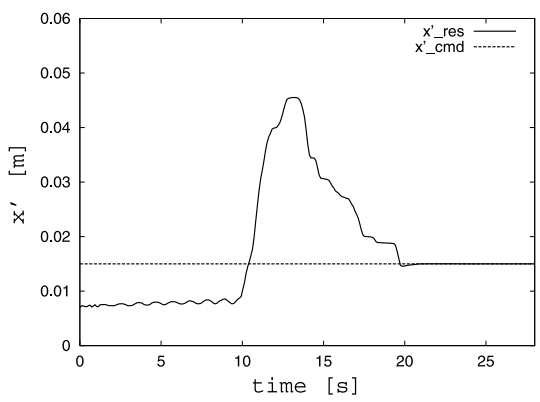

図 17 車輪の位置応答 (Case 2-2)

Fig. 17. Position response of wheels (Case 2-2).

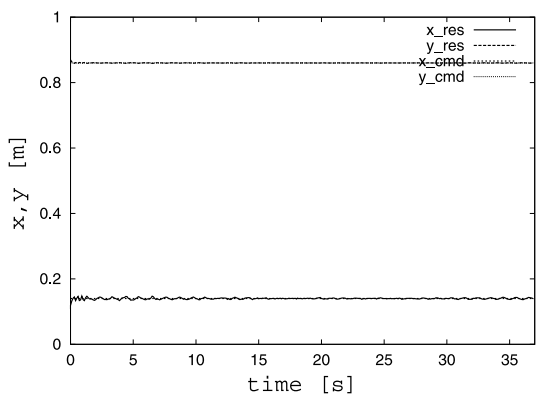

図 18 先端の位置応答 (Case 2-3)

Fig. 18. Position responses of end-effector (Case 2-3).

きに提案手法を適用した。眓 18〜図 20 にCase 2-3 のとき のそれぞれの先端位置，角度，車輪の応答を示す。

$\langle\mathbf{5} \cdot \mathbf{4}\rangle$ 実験結果と検討 すべての実験結果から, 受動 関節を含んだ移動マニピュレータは倒れることなく安定化 することができ，先端位置はそれぞれの指令值に収束した。 実験 1 から外乱による影響を受けなかったことより，提案 手法は外乱抑制に効果的であることがわかった。また，実 験 2 においても車輪の移動に対する安定性を示すことがで きた。これらの結果から, 提案手法の有効性を示すことが できた。しかし, 図 14, 図 17, 図 20 からわかるように実 験 2 では車輪の移動について予想外の過渡応答がみられた。 これは，車輪の移動を零空間動作で実現しているためであ り, 零空間制御では粘性摩擦に関係する過渡応答を十分に 抑制することができないからである。同点は，車輪のなめ らかな移動を達成するためには解決すべき問題であり, 将 来的な課題の 1 つとしたい。 


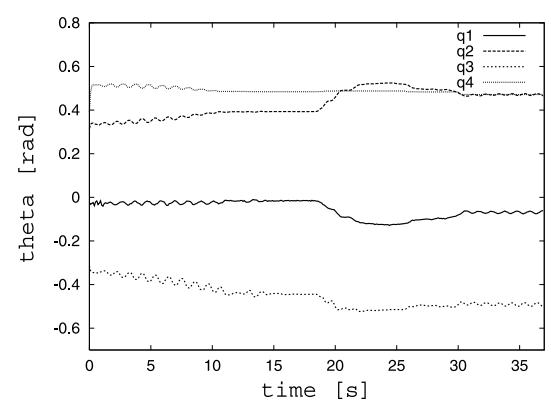

図 19 角度応答 (Case 2-3)

Fig. 19. Theta responses (Case 2-3).

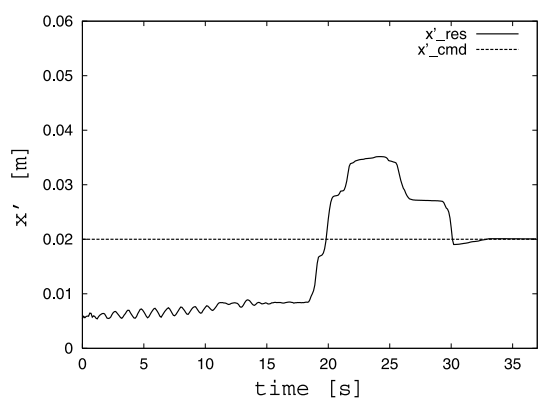

図 20 車輪の位置応答 (Case 2-3)

Fig. 20. Position response of wheels (Case 2-3).

\section{6. 結 論}

本論文では, 受動関節を含む 2 輪駆動型移動マニピュレー 夕の零空間動作における制御系設計を提案した。本研究の 目的は移動マニピュレータの先端位置を保ちながら安定化 させることと，先端位置を保ちながら車輪を目標位置まで 移動することである。この不安定なシステムの安定化には 作業空間オブザーバに基づく手法（位置制御）と零空間制 御を適用した。零空間の制御系は受動性に基づいたコント ローラを設計し，シミュレーションと実験により提案手法 の有効性を確認した。本論文は，受動性に基づく手法の零 空間の制御系設計への実現可能性を示しており，更に機構 的に不安定要素を含む咒長システムに対しても有効である ことを示している。

\section{謝 辞}

本研究の一部は, 文部科学省平成 15 年度 21 世紀 COE プログラム「知能化から生命化へのシステムデザイン」に よるものであることを記し，謝意を表す。

最後に，本論文を構成するに当たって慶應義塾大学・志 水清孝名誉教授に貴重な御助言をいただいたことに深く感 謝の意を述べる。

(平成 18 年 11 月 6 日受付，平成 19 年 6 月 6 日再受付)

$$
\text { 文献 }
$$

(1) S. Arimoto: "Control Theory of Non-linear Mechanical Systems", Oxford Science Publications (1996)

(2) O. Khatib: "A Unified Approach for Motion and Force Control of Robot
Manipulators: The Operational Space Formulation”, IEEE Trans. Robot Automat., Vol.RA-3, pp.43-53 (1987)

(3) T. Murakami, K. Kahlen, and R.W. De Doncker: "Robust Motion Control Based on Projection Plane in Redundant Manipulator", IEEE Trans. Ind. Electron., Vol.49, No.1, pp.248-255 (2002)

(4) T. Murakami and K. Ohnishi: "A Study of Stability and Workspace Decoupling Control Based on Robust Control in Multi-Degrees-of-Freedom Robot", IEEJ Trans. IA, Vol.113-D, No.5, pp.639-646 (1993-5) (in Japanese)

村上俊之・大西公平 :「ロバスト制御に基づいた多自由度ロボット の安定性および作業空間での非干渉制御に関する一考察」, 電学論 D, 113, 5, pp.639-646 (1993-5)

(5) N. Oda, T. Murakami, and K. Ohnishi: "A Robust Control Strategy of Redundant Manipulator by Workspace Observer", IEEJ Trans. IA, Vol.115-D, No.8, pp.991-998 (1995-8) (in Japanese)

小田尚樹・村上俊之・大西公平：「作業空間オブザーバに基づく㫕長マ ニピュレータのロバスト制御」, 電学論 D, 115, 8, pp.991-998 (1995-8)

(6) M.W. Spong, F.L. Lewis, and C.T. Abdallah: "Robot Control -Dynamics, Motion Planning, and Analysis", IEEE PRESS (1992)

(7) T. Shen and C. Ishii: "Robust Control Theory for Nonlinear Systems Based on Dissipatively", Advanced Academic Series, No.1, SICE (2002) (in Japanese)

申 鉄龍・石井千春：「消散性に基づく非線形系のロバスト制御一安 定性と外乱抑制一」, 先端学術シリーズ No.1, 計測自動制御学会 (2002)

(8) A. Van der Schaft: " $L_{2}$-Gain and Passivity Techniques in Nonlinear Control", Springer (1996)

(9) Q. Huang, S. Sugano, and I. Kato: "Stability Control for A Mobile Manipulator Using A Potential Method", Proceedings of the IEEE/RSJ/GI International Conference, Vol.2, pp.839-846 (1994)

(10) Q. Huang, S. Sugano, and I. Kato: "Stability Control for A Vehicle-Mounted Manipulator-Stability Evaluation Criteria and Manipulator Compensatory Motion-", Transóf SICE, Vol.31, No.7, pp.861-870 (1995-7) (in Japanese) 黄強・菅野重樹・加藤一郎：「ヴィークル搭載型マニピュレー 夕の安定化制御一安定規範とマニピュレータによる補償運動一」, 計 測自動制御学会論文集, 31, 7, pp.861-870 (1995-7)

(11) M. Hatano, T. Ohsumi, H. Obara, and M. Minami: "Stability Control for Mobile Manipulators Using Criteria Based on Reaction-1st Report, Modeling, Comparison with ZMP Criteria and Effects of Stability Compensation-", Trans. of RSJ, Vol.21, No.1, pp.63-71 (2003-1) (in Japanese)

羽多野正俊・大住 剛・小原治樹・見浪 護：「抗力規範による移 動マニピュレータの安定化制御一第 1 報, モデルの導出, ZMP 規 範との比較および安定化運度の効果一」, 日本ロボット学会誌, 21, 1, pp.63-71 (2003-1)

(12) T. Shiozaki and T. Murakami: "Posture Control of Mobile Robot by HandEye System Considering Nonholnomic Constraints", in Proceedings of the 2005 IEEE Conference on Control Applications, pp.215-220 (2005)

柴 田 剛 慶 (学生員) 1980 年 8 月 5 日生。 2003 年 3 月慶應

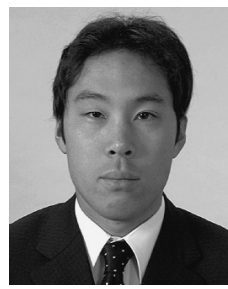
義塾大学理工学部システムデザイン工学科卒業。 2005 年 3 月同大学大学院理工学研究科総合デザ イン工学専攻修士課程修了。同年 4 月同大学大 学院同専攻後期博士課程入学。現在, ロボティク ス, モーションコントロール, 受動性理論の研究 に従事。

村 上 俊 之（正員） 1965 年 10 月 5 日生。 1993 年 3 月慶應

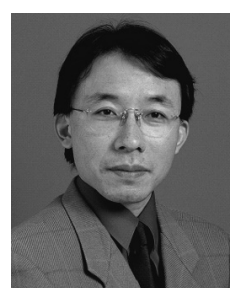
義塾大学大学院電気工学専攻博士課程修了。現在, 同大学理工学部システムデザイン工学科教授。工 学博士。 